Annals of Tropical Research, 33(1): 1-17 (2011)

\title{
Progress in Natural Resource Based Emission Reduction Activities in the Tropics
}

\author{
Sebastian Thomas \\ School of Business, University of Queensland, Brisbane, QLD 4072, Australia
}

\begin{abstract}
In this introduction to the Annals of Tropical Research special issue on natural resource based carbon offsets a framework is provided for describing the architecture of global climate policy instruments and market mechanisms, and the relationships between these components of the international climate change mitigation and adaptation landscape is discussed. The principal constraints and enabling factors for natural resource based offset projects are identified as issues of capacity, finance, governance and regulation. These concerns provide the rationale for a proposed research agenda, comprising conceptual research and capacity building, both of which can be enacted through the implementation of pilot project activities.
\end{abstract}

Keywords: carbon markets, offsets, CDM, REDD, conservation agriculture, carbon forestry, climate policy

\section{INTRODUCTION}

Carbon has become the currency of a new global market. This market has been designed to achieve two key outcomes, namely reduction of greenhouse gas emissions and sustainable development (UNFCCC, 1998). While the greenhouse effect is driven by a number of natural and anthropogenic forcings, it is apparent that human activities affect the planetary climate system (Rosenzweig et al., 2008; Sokolov et al., 2009). A prominent driver is carbon dioxide $\left(\mathrm{CO}_{2}\right)$, which is not only the predominant greenhouse gas but a fundamental component of earth's biogeochemistry. $\mathrm{CO}_{2}$ has become a benchmark in terms of its contribution to the greenhouse effect, and other natural and artificial atmospheric gases are measured against this reference. This benchmark has allowed for the quantification of greenhouse gas emissions and therefore the creation of a standard measurable and exchangeable unit. Carbon can be traded in commodity markets in the same manner as gold or iron ore. The basic element of life on earth, and from some perspectives the greatest threat to human civilization (e.g. Roston, 2008), has entered the vernacular. In the evolving economy of the 21st Century, 'carbon' is shorthand for a new commodity standard measured in metric tons of $\mathrm{CO}_{2}$ equivalent $\left(\mathrm{tCO}_{2} \mathrm{e}\right)$.

Climate change is being driven by human activities, namely land-use practices, land cover change, deforestation and the direct emission of greenhouse gases through industrial processes (Rosenzweig et al., 2008; Anderegg et al., 2010; van der Werf et 
al., 2010; Steffen et al., 2011). These factors create new conditions and feedbacks in the planet's environmental mechanisms that lead to substantial shifts in the parameters of ecological and biophysical systems. The impacts of climate change are increasing in severity and will continue to do so for the foreseeable future, posing recurring threats and long-term challenges to human communities and infrastructure as well as to ecosystem biodiversity. Environmental conditions are changing in ways and to degrees that will necessitate fundamental and severe revisions of human assumptions and practices about food security, land tenure and health (Veron et al., 2009; New et al., 2010; Steffen et al., 2010; Steffen et al., 2011).

In conjunction with a range of policy approaches at global and national scales, the international strategic response to the challenges of climate change relies heavily on market-based economic mechanisms, and specifically on emission 'offsets' generated by project activities (meaning undertakings or developments with specific temporal, spatial and economic boundaries) in developing countries (Dargusch et al., 2010). There is, however, widespread uncertainty and scepticism about the value of carbon offsets (Akter et al., 2009). The reasons for this include lack of understanding of the nature of offset mechanisms and doubts about the integrity of offset projects. The global offset market is also unbalanced, with some countries, regions and sectoral scopes greatly under-represented (Boyd et al., 2009). Most prominently, natural resource based offsets represent less than $2 \%$ of all projects, despite the reform efforts of regulatory agencies and the rise of voluntary schemes intended to redress this imbalance (Kossoy and Ambrosi, 2010; UNEP, 2010).

Countries in tropical zones are likely to experience the more extreme impacts of climate change and generally have less capacity to manage these projected effects, in terms of existing technical skills and funds available for adaptation (Stern, 2006; IPCC, 2007). Tropical countries in Africa, the Asia-Pacific and the Americas are therefore key stakeholders in international climate policy discussions. There is a need for innovative approaches to management practices in primary production and resource utilisation that integrate a range of perspectives (scientific, socio-economic and cultural) with the goal of achieving long-term sustainability of human communities and natural systems. In developing tropical countries faced with environmental and social challenges, there are synergies between the imperatives of improving food security and ecological sustainability, the requirements of international policy commitments, and the opportunities inherent in innovative approaches to natural resource management in relation to carbon.

The papers included in this special issue identify and examine critical aspects of this important field. This introductory article presents a framework that describes the global climate policy architecture within which carbon markets function. The framework includes the evolving 'Reducing Emissions from Deforestation and Degradation Plus mechanism (REDD+', which covers not only avoided deforestation as originally proposed but reducing emissions from forest degradation, conservation and enhancement of forest carbon stocks, and sustainable management of forests) and regulated and voluntary carbon market schemes. The paper then identifies the principal constraints, barriers and enabling factors in the development of natural resource based offset project activities. These can be characterised as issues of capacity, finance, governance and regulation. In the light of these issues, the paper 
proposes a practical research agenda, and identifies the ways in which the articles in this special issue address important research questions. Further papers in the issue explore the topics outlined in the introduction, including REDD+, the potential of carbon forestry, the Clean Development Mechanism (CDM), and new agricultural technologies in the form of conservation agriculture. The articles address the recurring themes of the constraints on offset project development and operation, the importance of effective governance systems, sources of project funding and the complex challenge of determining flexible yet specific definitions and methodologies for offset schemes.

\section{CARBON OFFSET MECHANISMS WITHIN THE INTERNATIONAL CLIMATE POLICY ARCHITECTURE}

The range of public and private sector climate policy instruments exist mainly beneath the umbrella of the United Nations Framework Convention on Climate Change (UNFCCC). Voluntary carbon offset schemes are not governed by the terms of the UNFCCC, but operate within markets established under the Kyoto Protocol. The structure of the global policy architecture is shown in schematic form in Figure 1.

While the UNFCCC is, in essence, a treaty between nations (or Parties to the Convention) agreeing that greenhouse gas emissions should be reduced, the Kyoto Protocol to the Convention establishes specific and binding reduction targets for individual developed countries, and clear responsibilities for developing countries. The Kyoto Protocol created three distinct mechanisms for achieving these reductions and responsibilities, namely the Clean Development Mechanism (CDM) and Joint Implementation (JI) - which allow for emission reduction projects to be implemented in partnership between developed and developing countries (in the case of the CDM) or between two developed countries in the case of the JI -and international emissions trading, which allows national governments to trade emission allowances (assigned to countries under the terms of the Kyoto Protocol) amongst themselves. Land use and forestry are included in these Kyoto mechanisms, but do not address the drivers of large-scale deforestation and forest degradation globally. As a result, the UNFCCC has pursued a separate policy agenda now formalised as REDD+, which is intended to operate between governments rather than through free markets. Voluntary offset certification schemes have been developed, principally by community-oriented organizations, to promote sustainability-focused projects that may be of interest to carbon market consumers motivated more by corporate responsibility philosophies than financial imperatives. 


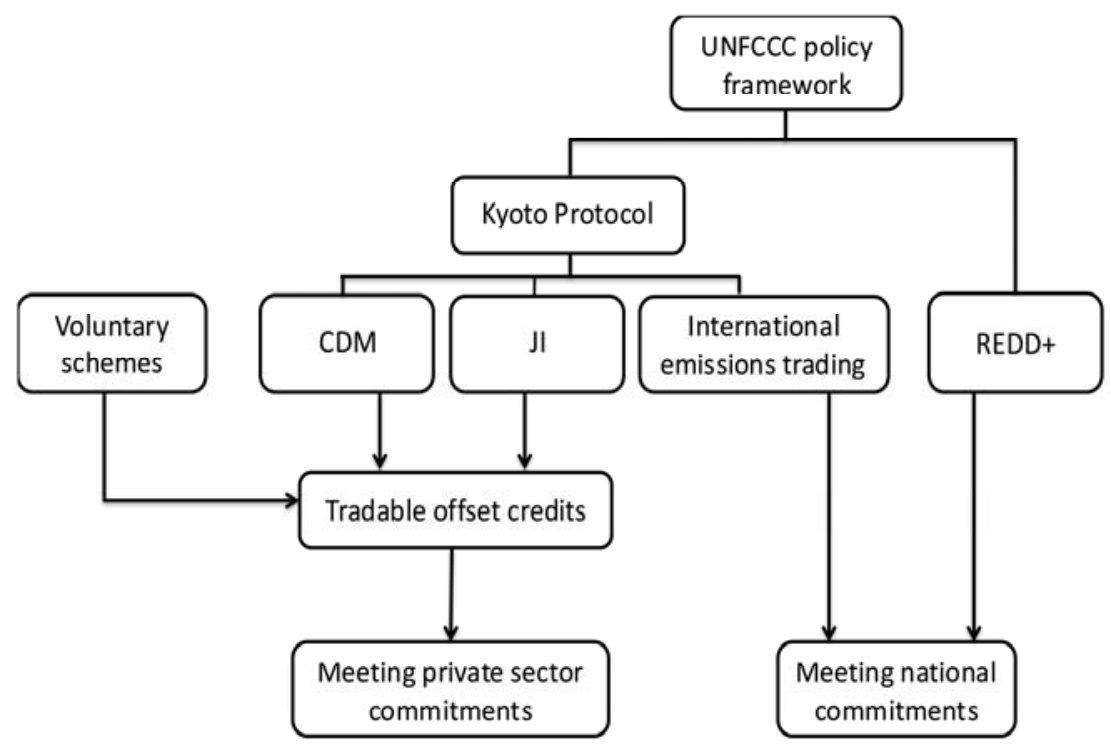

Figure 1. A framework describing the global climate policy and carbon market architecture

The international climate policy architecture is thus characterised by a mix of regulatory policy and market-based strategies. The evolving REDD+ mechanism supports efforts to preserve the planet's remnant forest zones and enhance the carbon storage capability of managed forest areas (by increasing the volume of carbon sequestered and improving the efficiency of management systems). This is seen as one of the most successful aspects of international policy negotiations conducted under the aegis of the UNFCCC. In its initial stages, the implementation of REDD+ activities is most likely to be achieved through government-to-government coordination. It is possible that REDD+ activities may eventually be eligible for participation in international markets, but this will take time and considerable development of the details of operational mechanisms (Anglesen et al., 2009). In contrast to REDD+ approaches, the Clean Development Mechanism and other project-oriented schemes function within market structures by generating tradable offset credits, which can be bought, sold and eventually retired under the terms of compliance legislation such as the European Union Emissions Trading Scheme and the Australian Clean Energy Plan. 


\section{CONSTRAINTS, BARRIERS AND ENABLING FACTORS IN OFFSET PROJECT DEVELOPMENT}

Table 1. Constraints, barriers and enabling factors in carbon offset activities

\begin{tabular}{lc}
\hline Capacity & Knowledge, networks, infrastructure \\
\hline Finance & Capital, transaction costs, delayed returns \\
Governance & Legitimacy, effectiveness \\
Regulation & Tenure, additionality, permanence \\
\hline
\end{tabular}

\section{Capacity as a Factor Affecting Carbon Offset Activities}

The capacity of individuals and organisations to develop and implement carbon offset projects or activities can be constrained by knowledge (or more accurately, knowledge deficiency) in a range of ways: lack of awareness of policy instruments, technologies and market opportunities (Qi et al., 2008; van der Gaast, 2009; Dargusch et al., this issue; Rosendal and Andresen, 2011); lack of data or the inability to collate necessary information (Ramachandran Nair et al., 2009; Pelletier et al., 2010); and inadequate levels of technical or operational skills (Thomas and Dargusch, 2010; Rochecouste and Dargusch, this issue).

Many of these concerns are explored in detail through national and regional case studies in this special issue. Lasco et al. (this issue) identified key knowledge deficiencies and trends in the Philippines forestry sector as determinants of the benefits likely to be derived by smallholders from various types of REDD+ activities. Dargusch et al. (this issue) investigated the constraints on carbon offset projects in the Pacific Island countries, which have unique characteristics and thus challenges, as well as opportunities. They noted a lack of awareness of carbon markets, in conjunction with a paucity of requisite technical skills, as key factors constraining offset project development in Pacific Island countries.

Networks (partnerships, linkages) allow for flows of information and knowledge, materials and services, and provide a range of facilitative opportunities for project developers and managers (Suneetha et al., 2011). Networks are an integral component of social capital, which contributes to resilience to climate impacts and the adaptive capacity of communities (Smit and Wandel, 2006; Tol et al., 2008). Networks can operate between individuals, professional associations, regional groups, communities, governments, businesses, environmental groups, and other types of collectives. Networks have the potential to not only open new opportunities based on synergies between the goals of different organisations (O'Connor, 2008), but also to facilitate advances in other areas discussed here, particularly infrastructure, transaction costs, legitimacy and effectiveness.

A third aspect of capacity relates not to social capacity but the capability of physical and technological infrastructure to facilitate the positive outcomes of offset projects. For the $57 \%$ of rural households in India that lack connection to grid electricity, for example, there is little likelihood that biomass-based renewable energy projects will make any difference unless funds are first provided to support the 
development of connectivity (Sirohi, 2007). Similarly, the ability of farmers in developing tropical countries to implement conservation agriculture practices including controlled traffic farming may require particular types of machinery (Rochecouste and Dargusch, this issue).

\section{Finance as a Factor Affecting Carbon Offset Activities}

Offset project development cannot occur without finance; funding is necessary for any novel economic activity. In the case of public forestry and land-use policy, governments are unlikely to consider alternative activities unless these offer a revenue stream at least comparable to returns from current practices (Osborne and Kiker, 2005). Investment in commercially oriented offset projects will not occur unless there is a likelihood of positive financial return (Hultman et al., 2010).

The rationale for climate policy instruments is to expand economic valuations to include costs traditionally considered as 'externalities', that is, costs which were incurred beyond the immediate boundaries of project activities, through use of common resources not readily perceived as directly related to the activity (Grubb et al., 2010). While approaches to economic valuation and benefit-cost analysis of carbon projects are evolving, it remains the case that financial considerations remain significant in natural resource based carbon offset activities, including the provision of investment capital, transaction costs incurred in project development, implementation and management, and the disincentive of delayed returns.

In the case of natural resource based projects, it is usually the case that investment is required to cover the costs of new technology (such as biogas digesters, or biomass electricity generators), materials (including seedlings), agricultural machinery, infrastructure (grid connections, field preparation) or training (Boyd et al., 2007; Gilau et al., 2007; Gong et al., 2010; Dargusch et al., this issue; Rochecouste and Dargusch, this issue; Smith et al., this issue).

Transaction costs are an inevitable component of any economic activity, and are one of the principal constraints in the development of CDM offset projects (Chadwick 2006; Thomas et al. 2010). In terms of CDM offset project development, transaction costs can be defined as those expenses that cannot be attributed to the physical process of reducing emissions nor the level of demand for offset credits. That is, if the project were undertaken without the expense, it would not result in additional greenhouse gas emissions, but would also not qualify for the issuance of offset credits (Chadwick, 2006). Offset project transaction costs are therefore those associated with project development (gathering baseline data, employing technical expertise), independent validation of project design details, annual verification and project administrative (e.g. Gong et al., 2010). Higher transaction costs limit the development of CDM projects, and thus restrict the mechanism's ability to fulfil its objectives. The rise of voluntary offset certification schemes with substantially less stringent registration requirements, and thus lower transaction costs, has in part occurred as a response to the costly complexities of CDM requirements.

Delayed returns are a characteristic of natural resource based offset projects. While it is relatively simple to identify emission reductions through the avoidance of emissions (as in the case of building a wind farm as an alternative to a coal-fired power station), actual sequestration of greenhouse gases through forestry takes time, 
and the issuance of carbon credits in these cases will be delayed until the trees (for instance) have grown. In the case of carbon forestry projects, it will generally be the case that if initial offset credit payments are received after the first payments for an alternative opportunity, high discount rates will result in the net present value of project revenue (carbon payments) being less than that of the alternative (i.e. the baseline scenario, without the offset project development). In addition, where natural resource based offset projects require substantial initial investment with the expectation of future return, but no guarantee (as forests for instance are vulnerable to weather patterns and natural disasters), small-scale project operators are unlikely to participate (Gong et al., 2010).

\section{Governance as a Factor Affecting Carbon Offset Activities}

Governance systems are critical in terms of both project development potential and host-country investment attractiveness, and are likely to influence offset project effectiveness at all levels. Carbon governance can be understood in terms of its legitimacy and effectiveness (Lederer, 2011).

Legitimacy is the notion that regulations should be obeyed because of their merits and innate virtue rather than because of coercion or self-interest (Hurd, 1999). While regulated offset projects under the CDM can be considered to have a steadily increasing degree of procedural legitimacy (Lederer, 2011), the sustainability outcomes of these activities are less clear. Voluntary project mechanisms, by virtue of their social and environmental agendas, are likely to be considered more legitimate offset instruments than their market-oriented counterparts. Legitimacy, however, must be considered not only in terms of horizontal comparisons but also in its vertical integration and impacts, meaning the extent to which policies and actions are proposed, developed and accepted by stakeholders at different levels, from national government to regional agencies to local communities and individuals. Legitimacy will be an absolutely critical consideration in the development of REDD+ programs in tropical forest countries, as these different stakeholders will need to not only accept policy approaches but also collaborate effectively in their implementation to achieve successful REDD+ outcomes.

One aspect of legitimacy that must be considered in the implementation of offset activities, particularly in the case of public instruments such as REDD+, is the fact that stakeholders who provide or control funding streams are likely to be those responsible for establishing operational processes and accountability criteria (Rosendal, 2011). Thus, it may often be the case that mechanisms will be designed to suit the priorities of investors rather than operators. Rochecouste and Dargusch (this issue), for instance, highlight the importance of global regulatory frameworks for new approaches to carbon management and sequestration for conservation agriculture, which is a goal-oriented approach to farming considered to have the potential to reduce carbon emissions through changes in land management practices and direct soil carbon sequestration. While agricultural sectors in developing countries have the capacity to be innovative and proactive in soil carbon management, biological carbon sequestration and improvements in technical processes, there is a clear need for the establishment of efficient trading mechanisms to encourage these new strategies. Yet the integration of local agricultural practices with new international market 
instruments can only occur when the characteristics of the local practices are considered in the design of the new policy instrument. Similarly, Dargusch et al. (this issue) argue that in order to facilitate the genuine potential of Pacific Island countries to engage in international carbon markets, a regional approach needs to be taken to project registration and supervision. In order to be legitimate in the eyes of all stakeholders, these international (horizontal) relationships will need to be inclusive, transparent and comprehensive, and take into account the needs of local stakeholders and characteristics of local contexts.

Legitimacy also operates vertically. Multi-level, multi-actor governance is critical to achieving successful outcomes in circumstances where the range of stakeholders includes multiple government agencies at local, regional and national scales, communities and commercial organisations, as well as NGOs, indigenous peoples and illegal or unrecognised actors. Medrilzam et al. (this issue), for instance, identify institutional fragmentation as the main impediment to the successful implementation of REDD+ schemes in Indonesia, and Farhan et al. (this issue) demonstrate the impacts of jurisdictional overlap and regulatory contradiction in the same country. Indonesia is the world's third largest emitter of greenhouse gases, and $80 \%$ of its emissions derive from land use, land-use change and forestry (LULUCF) activities. Successful development and continuing reform of policy mechanisms are therefore integral to a successful international climate mitigation strategy.

The effectiveness of offsetting schemes and projects, despite the certainty of being interpreted differently by various stakeholders, can be gauged not only by the extent of emission reductions, but also by the success of technology transfer and capacity building, and the replacement of unsustainable industrial and land use practices with socially and environmentally positive alternatives. A critical consideration in the development of REDD+ activities, for instance, is finding ways to decrease the demand for the forest products that drives deforestation (Skutsch and McCall, 2010). It is not simply a question of providing alternative income streams for loggers in tropical forest countries; as long as there is demand, substitutes will need to be found for the goods and services that logging and forest degradation provide.

In commercial activities involving multiple parties and business between international partners, governance systems serve to shape the investment landscape (Jung, 2006; Thomas et al., 2011). Smith et al. (this issue), for instance, associate the growing success of the CDM in Vietnam with that country's economic and administrative reform strategies, which have created an attractive climate for international investment, yet shaped this environment to suit the particular development priorities of Vietnam. While this harnessing of synergistic interests is bringing much-needed investment into the country, these authors note the preponderance of project activities that are likely to have negative social and ecological impacts. The importance of striking a balance between development priorities and sustainable environmental management is clear.

\section{Regulation as a Factor Affecting Carbon Offset Activities}

Land tenure is a crucial consideration in natural resource based carbon offset activities, and can be understood as the statutory or customary right of an individual or group to hold and use an area of land and its associated resources, for a period of time 
and under particular conditions (e.g. Sunderlin, Larson and Cronkleton, 2009). Tenure is an issue that exemplifies the complex nature of the subjects explored in this special issue. Most forests in tropical countries, for instance, are inhabited and exploited by local communities, for fuel and building materials, food sources, medicines, and other economic and cultural activities. While some national governments might consider moving traditional inhabitants from their customary land as a simple means of ensuring forest integrity and avoiding deforestation, research suggests that community-based forest management is in fact more likely to preserve and enhance carbon stocks than direct forest protection, because the latter tends to foster illegal activities and unmonitored degradation (Porter-Bolland et al., 2011).

Medrilzam and Dargusch (this issue) demonstrate the importance of policy design in the context of REDD+ forestry definitions, including determinations of land ownership and management boundaries, which can inhibit the ability of tropical countries to implement forestry-related offset projects. They highlight the potential negative consequences of unclear tenure on REDD+ activities, including the failure to effectively engage communities in forest management. Lasco et al. (this issue) also note that the design of REDD+ components has immediate relevance to the benefits accruing to smallholders from REDD+ implementation. These authors discuss the challenges arising from diverse and complex tenure arrangements, and possible solutions to tenure issues (using examples from the Philippines) relating to traditional and indigenous landownership.

The concept of additionality is fundamental to the development of offset projects, but has been criticized as inherently paradoxical, and often likely to encourage perverse outcomes (Bode and Michaelowa, 2003). The principal meaning of additionality is that emission reductions (against a 'business as usual' baseline scenario) resulting from the project activity would not have occurred in the absence of the project (UNFCCC, 2011). Additionality is also used to mean that projects could not occur without revenue or finance derived from the sale of offset credits. Yet these requirements can be considered disincentives to countries to implement regulatory reform requiring improved environmental practices (Bode and Michaelowa, 2003). The nature of carbon equivalency results in some project types being much more attractive than others, based on the greenhouse gas that is the source of the emission reductions in the project scenario. One metric ton of methane is the equivalent of 21 tons of carbon dioxide (or $21 \mathrm{tCO} 2$ ), and a metric ton of hydroflurocarbon gas (e.g. HFC-23) can equate to almost 12,000 tCO2e. In China, investment in marginal biomass energy projects is considered possible with CDM financing, for example, but only in conjunction with a range of external factors, such as the supply of biomass, the availability of technology, institutional support and funding sources. In contrast, projects involving emission reductions from the destruction of industrial gases are achievable, and financially attractive, with CDM financing alone (Wang and Chen, 2010). Rochecouste and Dargusch (this issue) suggest that the small additionality margins available in agricultural projects demand fresh consideration of the requirement of additionality, because the generic approach applied to assess additionality is clearly inadequate to address the needs and characteristics of diverse sectors and regional contexts. 
In addition to the potentially perverse nature of the concept, the independent assessment of additionality (as required under the CDM, VCS and other voluntary schemes) is highly subjective. Many project applications cite additionality criteria that lack credibility or rigour; at the same time the agencies evaluating project design documents frequently fail to provide clear statements explaining how barriers (including the requirement of additionality) were assessed as valid or realistic (Schneider, 2009). Analysis of project design documents and validation reports suggests that more ambitious benchmarks and rigorous standards are necessary to address these issues (Olsen, 2007; Sutter and Parreño, 2007; Bushnell, 2010).

Permanence is a critical issue in land use and forestry offset activities. Permanence can be understood as the longevity of an emission reduction. Offsets generated from avoided emissions or the destruction of industrial gases are considered permanent reductions. In contrast, carbon sequestered in natural systems including forests is considered to be at risk (from fire, logging or other hazards) and is treated as nonpermanent under the terms of the CDM. Offset credits derived from forestry projects are deemed either temporary, expiring at the end of the of the commitment period subsequent to the one in which they were issued, or long-term, expiring at the end of the crediting period for the project (UNFCCC, 2005). This is considered to be a disincentive for investment in natural resource based project activities (IETA, 2009; Thomas et al., 2010).

The issue of permanence in natural systems might be solved in a number of ways, including the requirement (or option) to return received credits in the case of loss of carbon stocks, imposition of legal obligations for future owners to preserve carbon stocks, and the creation of reserve funds to provide a store of unused credits as insurance against loss of stocks (IETA, 2009; DCCEE, 2010). Existing policy regulations regarding the permanence of natural resource based offset activities are inhibiting these project activities and as result limiting the sustainability outcomes of carbon offset instruments. The rules around permanence warrant serious review and reform in order to facilitate the co-benefits associated with natural resource based project activities (Dutschke and Anglesen, 2008; Boyd et al., 2009).

\section{A PRACTICAL RESEARCH AGENDA}

While there are constraints on the development and implementation of natural resource based emission reduction activities, these project types nevertheless offer considerable opportunities in terms of climate change mitigation and sustainable development (Jung, 2005; Schlamadinger and Johns, 2007). Afforestation, reforestation, avoided deforestation and forest degradation, soil organic carbon management, conservation agriculture and the carbon services of aquatic ecotypes are novel research fields with considerable potential in terms of carbon sequestration and ecosystem services including the provision of habitat, production of food, regulation of local climate and disease vectors, nutrient cycling and pollination, and the stabilization and protection of landscapes (Costanza et al., 1997; Ribaudo et al., 2010).

Investment in offset project development in the tropics offers the dual benefits of financial return and positive socio-economic and sustainability outcomes. The 
financial aspects of natural resource based offset projects are integral to the development of this aspect of carbon markets (Masera et al., 1997; Torres et al., 2010). In most cases natural resource based project activities also provide non-market benefits in the form of ecosystem services, biodiversity conservation, and enhanced adaptive capacity for communities threatened by climate change (Trumper et al., 2009; Venter et al., 2009; Sathirathai and Barbier, 2001).

A suitable approach to addressing the constraints and imbalances identified here is a research agenda comprising three core aspects. These components are conceptual research, capacity building, and pilot project development and implementation. This approach will facilitate the removal of barriers affecting natural resource based offset activities, and provide practical examples to guide future project development and implementation.

\section{Conceptual research in natural resource based offset policy}

Research is necessary to address a number of conceptual and definitional gaps and inadequacies in the field of natural resource based offsets. Firstly, the current distinction between mitigation and adaptation should be reconsidered. While reducing greenhouse emissions remains a priority, and involves reforming the socio-economic landscape (by reforming agricultural and industrial bases) as well as pursuing new technological and sociological paradigms, adapting to climate change is a necessity. Mitigation and adaption have been, to date, understood as separate functions, but this may no longer be a relevant distinction, particularly considering the long-term inevitability of climate change. Natural resource based offsetting, which can also be thought of as carbon-oriented management of social-ecological systems, is the ideal vehicle for this conceptual shift. There is an opportunity to pursue what might be termed adaptive mitigation Evidence-based theoretical and empirical research is vital to the establishment of effective, efficient and equitable policy design (Angelsen et al., 2009), and the papers in this special issue represent steps towards that goal.

At the same time as new approaches to mitigation and adaptation are developed, there is an opportunity to question the validity and utility of other concepts central to climate policy. In particular, and importantly in the case of natural resource based offsets, there is a clear need to revisit the notions of business-as-usual baselines, additionality and permanence. Not only do these unduly constrain the development of project activities involving natural systems, but they also have the potential to create perverse incentives and outcomes in both policy frameworks and markets.

\section{Capacity building in natural resource based offset project activities}

Capacity building is a term that can apply across the full range of issues discussed in this paper. The pursuit of greenhouse gas emission reductions, positive environmental management and sustainable development entails setting priorities including the improvement of governance mechanisms and relationships, establishing networks to enhance market access, technology transfer and socio-political connectivity, and public-private partnerships to create training systems and financial flows across regions.

Capacity building can occur through government-to-government interactions, public-private partnerships, commercial enterprise (business relationships) and 
community development. Capacity building should be an integral feature of all carbon offset activities.

Pilot projects as integrated approaches to knowledge development and capacity building

In order to facilitate conceptual research and capacity building, in light of the barriers and enabling factors discussed in this article, a suitable pathway would involve the establishment of pilot projects in a range of key areas. REDD+ pilot projects have begun to operate in a number of countries, and there are opportunities for these activities to be expanded, potentially at smaller scales and in other regions. There are more than 8000 carbon offset projects in the regulated and voluntary markets either registered or in development, yet the issues identified in this paper, and throughout this special issue, remain. Natural resource based carbon offset activities are significantly under-represented in the global carbon markets and policy frameworks. There is a need for global institutions and national governments to initiate targeted experimental activities incorporating the research and capacity building agendas outlined above. By pursuing such a course, many of the constraints discussed here can be addressed, but a specific, focused and supported approach will be necessary. Targeted pilot projects offer the opportunity for these concerns to be managed in an integrated manner.

\section{CONCLUSION}

There are gaps and contradictions in the evolving international climate policy architecture. Natural resource based emission reduction activities and offset projects are poorly represented in global carbon markets, and constrained not only by the inherent characteristics of environmental and resource management but also by the peculiarities of regulatory systems in which they must operate.

The mix of large-scale government to government public policy approaches, exemplified by REDD+, and private sector commercially oriented project-based activities is an attempt to comprehensively address the climate change and sustainability challenges facing our civilisation in the 21st century. Yet this melange of approaches has already resulted in a fundamentally dysfunctional dichotomy. Large-scale public mechanisms such as REDD+, which have the potential to make significant contributions to social and environmental sustainability outcomes, face a range of substantial challenges, but one of the foremost is the issue of financing. As REDD+ is not a market instrument at present, the private sector has shown little interest in participating in these schemes. On the other hand, the more commercially attractive avenue of generating project-based carbon offset credits is, by its nature, far less likely to result in broader positive impacts for communities and ecosystems. The voluntary offset schemes that attempt to redress this predicament have a limited share of the market, and are yet to achieve a mainstream impact.

The task of researchers, policy makers, community organisations and project developers now is to explore how this dilemma might be resolved. The papers presented in this issue therefore examine a range of key aspects of the climate policy and carbon offset discussion, presenting novel research and important findings in the 
field of natural resource based offsetting. It is hoped that this special issue of Annals of Tropical Research will bring these important topics to a wider audience, and be of value to all readers.

\section{REFERENCES}

AKTER, S., BROUWER, R., BRANDER, L. and P. VAN BEUKERING. 2009. Respondent uncertainty in a contingent market for carbon offsets. Ecological Economics. 68(6): 1858-1863.

ANDEREGG, W.R.L., PRALL, J.W., HAROLD, J. and S.H. SCHNEIDER. 2010. Expert credibility in climate change. PNAS 21 June 2010. doi: 10.1073/pnas.1003187107.

ANGELSEN, A., BROCKHAUS, M., KANNINEN, M., SUNDERLIN, W. and S. WERTZ-KANOUNNIKOF. 2009. Realising REDD+: National strategy and policy options. Centre for International Forestry Research (CIFOR), Bogor, Indonesia.

BODE, S. and A. MICHAELOWA. 2003. Avoiding perverse effects of baseline and investment additionality determination in the case of renewable energy projects. Energy Policy. 31(6): 505-17.

BOYD, E., GUTIERREZ, M. and M. CHANG. 2007. Small-scale forest carbon projects: adapting CDM to low-income communities. Global Environmental Change. 17: 250-259.

BOYD, E., HULTMAN, N., TIMMONS ROBBINS, J., CORBERA, E., COLE, J., BOZMOSKI, J., EBELING, J., TIPPMAN, R., MANN, P., BROWN, K. and D. LIVERMAN. 2009. Reforming the CDM for sustainable development: lessons learned and policy futures. Environmental Science and Policy. 12(7): 820-831.

BUSHNELL, J.B. 2010. The Economics of Carbon Offsets. Working Paper 16305. National Bureau of Economic Research.

CHADWICK, B.P. 2006. Transaction costs and the clean development mechanism. Natural Resources Forum. 30: 256-271.

COSTANZA, R., D'ARGE, R., DE GROOT, R., FARBER, S., GRASSO, M., HANNON, B., LIMBURG, K., et al. 1997. The value of the world's ecosystem services and natural capital. Nature. 387: 253-260.

DARGUSCH, P., HARRISON, S. and S. THOMAS. 2010. A review of the constraints and opportunities for small-scale landholders to engage in forest-related carbon markets. Small-scale Forestry. 9(4): 397-408.

DCCEE (DEPARTMENT OF CLIMATE CHANGE AND ENERGY EFFICIENCY). 2010. Carbon Farming Initiative Consultation Paper. Australian Government, Canberra.

DUTSCHKE, M. and A. ANGELSEN. 2008. How do we ensure permanence and assign liability? In: Moving Ahead with REDD - Issues, Options and Implications, CIFOR, 2009. pp. 77-85. 
FORSYTH, T. 2009. Multilevel, multiactor governance in REDD+ participation, integration and coordination. In: A. Angelsen, M. Brockhaus, M. Kanninen, W. Sunderlin, and S. Wertz-Kanounnikof (eds), Realising REDD+: National Strategy and Policy Options. Centre for International Forestry Research (CIFOR), Bogor, Indonesia. pp. 113-122.

GILAU, A.M, VAN BUSKIRK, R. and M.J. SMALL. 2007. Enabling optimal energy options under the Clean Development Mechanism. Energy Policy. 35(11): 5526-5534.

GONG, Y., BULL, G. and K. BAYLIS. 2010. Participation in the world's first clean development mechanism forest project: the role of property rights, social capital and contractual rules. Ecological Economics. 69(6): 12921302.

GRUBB, M., LAING, T., COUNSELL, T. and C. WILLAN. 2010. Global carbon mechanisms: lessons and implications. Climatic Change. 104(3-4): 539573.

HULTMAN, N.E., PULVER, S., GUIMARÃES, L., DESHMUKH, R. and J. KANE. 2010. Carbon market risks and rewards: Firm perceptions of CDM investment decisions in Brazil and India. Energy Policy. (August 8): 1-13.

HURD, I. 1999. Legitimacy and authority in international politics. International Organization. 53: 379-408.

IETA (International Emissions Trading Association). 2009. State of the CDM 2009. Washington DC.

JUNG, M. 2005. The role of forestry projects in the clean development mechanism. Environmental Science and Policy. 8(2): 87-104.

JUNG, M. 2006. Host country attractiveness for CDM non-sink projects. Energy Policy. 34(15): 2173-2184.

KOSSOY, A. and P. AMBROSI. 2010. State and Trends of the Carbon Market 2010. World Bank, Washington DC.

MASERA, O., BELLON, M.R. and SEGURA, G. 1997. Forestry options for sequestering carbon in Mexico: Comparative economic analysis of three case studies. Critical Reviews in Environmental Science and Technology 27(special issue): 227-244.

NEW, M., LIVERMAN, D., SCHRODER, H. and K. ANDERSON. 2010. Four degrees and beyond: the potential for a global temperature increase of four degrees and its implications. Philosophical Transactions of the Royal Society A: Mathematical, Physical and Engineering Sciences. 369(1934): 6-19.

O'CONNOR, D. 2008. Governing the global commons: Linking carbon sequestration and biodiversity conservation in tropical forests. Global Environmental Change. 18(3): 368-374.

OLSEN, K.H. 2007. The clean development mechanism's contribution to sustainable development: a review of the literature. Climatic Change. 84(1): 59-73. 
OSBORNE, T. and C. KIKER. 2005. Carbon offsets as an economic alternative to large-scale logging: a case study in Guyana. Ecological Economics. 52(4): 481-496.

PELLETIER, J., KIRBY, K. and C. POTVIN. 2010. Significance of carbon stock uncertainties on emission reductions from deforestation and forest degradation in developing countries. Forest Policy and Economics. 12(7): 497-504.

PORTER-BOLLAND, L., ELLIS, E.A., GUARIGUATA, M.R., RUIZ-MALLÉN, I., YANKELEVICH, S. and V. REYES-GARCÍA. 2011. Community managed forests and forest protected areas: an assessment of their conservation effectiveness across the tropics. Forest Ecology and Management (Available online 20 June 2011).

QI, Y., MA, L., ZHANG, H. and H. LI. 2008. Translating a global issue into local priority: china's local government response to climate change. The Journal of Environment and Development. 17(4): 379-400.

RAMACHANDRAN NAIR, P.K., MOHAN KUMAR, B. and V.D. NAIR. 2009. Agroforestry as a strategy for carbon sequestration. Journal of Plant Nutrition and Soil Science. 172(1): 10-23.

RIBAUDO, M., GREENE, C., HANSEN, L. and D. HELLERSTEIN. 2010. Ecosystem services from agriculture: steps for expanding markets. Ecological Economics. 69(11): 2085-2092.

ROSENDAL, G.K. and S. ANDRESEN. 2011. Institutional design for improved forest governance through REDD: lessons from the global environment facility. Ecological Economics. 70: 1908-1915.

ROSENZWEIG, C., KAROLY, D., VICARELLI, M., NEOFOTIS, P., WU, Q., CASASSA, G., MENZEL, A., ROOT, T.L., ESTRELLA, N., SEGUIN, B., TRYJANOWSKI, P., LIU, C., RAWLINS, S. and A. IMESON. 2008. Attributing physical and biological impacts to anthropogenic climate change. Nature. 453: 353-357.

ROSTON, E. 2008. The Carbon Age: How Life's Core Element Has Become Civilization's Greatest Threat. Walker and Company, New York.

SATHIRATHAI, S. and E. BARBIER. 2001. Valuing mangrove conservation in southern Thailand. Contemporary Economic Policy. 19(2): 109-122.

SCHLAMADINGER, B. and T. JOHNS. 2007. Afforestation, Reforestation and reduced deforestation to sequester carbon and reduce emissions. In: P.H. Freer-Smith, M.J.S. Broadmeadow and J.M. Lynch (eds), Forestry and Climate Change. CAB International, Wallingford.

SCHNEIDER, L. 2009. Assessing the additionality of CDM projects: practical experiences and lessons learned. Climate Policy. 9(3): 242-254.

SIROHI, S. 2007. CDM: Is it a 'win-win' strategy for rural poverty alleviation in India? Climatic Change. 84(1): 91-110. doi:10.1007/s10584-007-9271-2.

SKUTSCH, M.M. and M.K. MCCALL. 2010. Reassessing REDD: governance, markets and the hype cycle. Climatic Change. 100(3-4): 395-402. 
SMIT, B., and J. WANDEL. 2006. Adaptation, adaptive capacity and vulnerability. Global Environmental Change. 16(3): 282-292.

SOKOLOV, A.P., STONE, P.H., FOREST, C.E., PRINN, R., SAROFIM, M.C., WEBSTER, M., PALTSEV, S. et al. 2009. Probabilistic forecast for twenty-first-century climate based on uncertainties in emissions (without policy) and climate parameters. Journal of Climate. 22(19): 5175-5204.

STEFFEN, W., SIMS, J., WALCOTT, J. and G. LAUGHLIN. 2010. Australian agriculture: coping with dangerous climate change. Regional Environmental Change. 11(S1): 205-214.

STEFFEN, W., PERSSON, A., DEUTSCH, L., ZALASIEWICZ, J., WILLIAMS, M., RICHARDSON, K., CRUMLEY, C. et al. 2011. The Anthropocene: from global change to planetary stewardship. AMBIO. 40(7): 739-761. doi:10.1007/s13280-011-0185-x.

STERN, N. 2006. The Economics of Climate Change: the Stern Review. Cambridge University Press, Cambridge.

SUNEETHA, M.S., RAHAJOE, J.S., SHOYAMA, K., LU, X., THAPA, S. and A.K. BRAIMOH. 2011. An indicator-based integrated assessment of ecosystem change and human-well-being: selected case studies from Indonesia, China and Japan. Ecological Economics. 70: 2124-2136.

SUNDERLIN, W.D. and P. CRONKLETON 2009. Forest tenure rights and REDD+ From inertia to policy solutions. In: A. Angelsen, M. Brockhaus, M. Kanninen, W. Sunderlin and S. Wertz-Kanounnikof (eds), Realising REDD+: National Strategy and Policy Options. Centre for International Forestry Research (CIFOR), Bogor, Indonesia. pp. 139-149.

SUTTER, C. and J. CARLOS PARREÑO. 2007. Does the current Clean Development Mechanism (CDM) deliver its sustainable development claim? An analysis of officially registered CDM projects. Climatic Change. 84(1): 75-90. doi:10.1007/s10584-007-9269-9.

THOMAS, S., DARGUSCH, P., HARRISON, S. and J. HERBOHN. 2010. Why are there so few afforestation and reforestation Clean Development Mechanism projects? Land Use Policy. 27(3): 880-888.

THOMAS, S. and P. DARGUSCH 2011. Engaging with carbon markets: the Libya case. Journal of Political Ecology. 18: 25-37.

THOMAS, S., DARGUSCH, P. and A. GRIFFITHS. 2011. The drivers and outcomes of the Clean Development Mechanism in China. Environmental Policy and Governance. 21: 223-239.

TOL, R.S.J., KLEIN, R.J.T. and R.J. NICHOLLS. 2008. Towards successful adaptation to sea-level rise along Europe's coasts. Journal of Coastal Research. 242: 432-442.

TORRES, A.B., MARCHANT, R., LOVETT, J.C., SMART, J.C.R. and TIPPER, R. 2010. Analysis of the carbon sequestration costs of afforestation and reforestation agroforestry practices and the use of cost curves to evaluate their potential for implementation of climate change mitigation. Ecological Economics. 69(3): 469-477. 
TRUMPER, K., BERTZKY, M., DICKSON, B., VAN DER HEIJDEN, G., JENKINS, M. and P. MANNING. 2009. The Natural Fix? The Role of Ecosystems in Climate Mitigation. A UNEP Rapid Response Assessment. United Nations, Cambridge.

UNEP (UNITED NATIONS ENVIRONMENT PROGRAM). 2010. CDM/JI Pipeline Analysis and Database. www.cdmpipeline.org. Accessed 1 May 2010.

UNFCCC (United Nations Framework Convention on Climate Change). 1998. Kyoto Protocol - Article 12. United Nations, Kyoto.

UNFCCC. 2001. The Marrakesh Accords and the Marrakesh Declaration. Available at: http://unfccc.int/cop7/documents/accords_draft.pdf.

UNFCCC. 2005. FCCC/KP/CMP/2005/8/Add./5/CMP.1. http://unfccc.int/ resource/docs/2005/cmp1/eng/08a01.pdf\#page $=61$.

UNFCCC. 2010. United Nations Framework Convention on Climate Change Clean Development Mechanism. http://cdm.unfccc.int/index.html. Accessed 1 October 2010.

VANDERGAAST, W, BEGG, K. and A. FLAMOS. 2009. Promoting sustainable energy technology transfers to developing countries through the CDM. Applied Energy. 86(2): 230-236.

VAN DER WERF, G.R., RANDERSON, J.T., GIGLIO, L., COLLATZ, G.J., MU, M., KASIBHATIA, P.S., MORTON, D.C., DEFRIES, R.S., JIN, Y. and T.T. VAN LEEUWEN. 2010. Global fire emissions and the contribution of deforestation, savannah, forest, agricultural, and peat fires (1997-2009). Atmospheric Chemistry and Physics Discussions. 10: 1615316230.

VENTER, O., MEIJAARD, E., POSSINGHAM, H., DENNIS, R., SHEIL, D., WICH, S.,HOVANI, L. and K. WILSON. 2009. Carbon payments as a safeguard for threatened tropical mammals. Conservation Letters. 2(3): 123-129.

VERON, J.E.N., HOEGH-GULDBERG, O., LENTON, T.M., LOUGH, J.M., OBURA, D.O., PEARCE-KELLY, P., SHEPPARD, C.R.C., SPALDING, M., STAFFORD-SMITH, M.G. and A.D. ROGERS. 2009. The coral reef crisis: the critical importance of $<350 \mathrm{ppm}$ CO2. Marine Pollution Bulletin. 58(10): 1428-1436. doi:10.1016/j.marpolbul.2009.09.009.

WANG, Q. and C. YONG. 2010. Barriers and opportunities of using the clean development mechanism to advance renewable energy development in China. Renewable and Sustainable Energy Reviews. 14(7): 1989-1998. doi:10.1016/j.rser.2010.03.023.

WANG, W. and LI, X. 2009. Ecological construction and sustainable development in China: The case of Jiaxing Municipality. In: W.W. Clark (ed.), Sustainable Communities. Springer, New York. pp. 223-241. 